CORRECTIONS

\title{
Phimosis in childhood
}

The authors of this Practice article have alerted us to an error in the penultimate paragraph (BMJ 2013;346:f3678, doi:10. 1136/bmj.f3678). The last sentence recommends that in refractory cases of balanoposthitis or balanitis, "a combined steroid and antibiotic cream (such as Fucidin) ... for a bacterial infection may be useful." In fact, Fucidin is just an antibiotic, and it is Fucidin $\mathrm{H}$ that is a combined steroid and antibiotic cream. For further comment from the authors on phimosis and its treatment, please see their full rapid response at http://www. bmj.com/content/346/bmj.f3678/rr/660544

Cite this as: BMJ 2013;347:f5632

๑ BMJ Publishing Group Ltd 2013 